\title{
EDITORIAL
}

\section{Anti-vaccine Campaign; Ethical Concerns}

\author{
Shabih H. Zaidi \\ How to cite this article: Zaidi SH. Anti-vaccine campaign, ethical concerns. \\ Ann Jinnah Sindh Med Uni 2020; 6(1):1-2 \\ DOI:https://doi.org/10.46663/ajsmu.v6i1.1-2
}

\begin{abstract}
'And whosoever saveth the life of one it shall be as if he had saved the life of all mankind"1.

The Noble Quran has clearly mandated that every life is precious. And yet, the recent stories of loss of life at the hands of a nanoparticle is a blatant reminder of the vulnerability and mortality of mankind - A virus whose weight was measured at 0.85 attograms or about one millionth of a trillion grams. It appears that the entire planet full of 7 billion human beings is at the feet of just 1 gram of viral load. And yet man is arrogant! Johns Hopkins Coronavirus resource centre announced $3,596,142$ confirmed cases on 5 May 2020. With total 251,718 deaths, in 187 countries, and rising. ${ }^{2}$ The virus did not differentiate between the rich and the poor, the powerful and the powerless, developed or developing, as it hit the British Prime Minister Boris Johnson with near enough the same ferocity as Dr Furqan of Karachi. Boris survived due to timely intervention, Furqan succumbed due to lack of it. The blame game has already started. More than 100 health professionals, primarily of Asian and African descent have already succumbed in the U.K. The delay or inefficient supply of PPE has been a matter of much debate here. What a tragedy indeed!
\end{abstract}

Rationing despite ample resources in the wealthy countries can hardly be justified.

Earlier on, we saw crops after crops of people dying, in each country, right from Wuhan to the outposts of Northern Canadian territories. Some cities like London, Rome, New York could not even find appropriate burial places for their dead.

Pandemics are known to change the direction of human history. The world does not remain the same once the pandemics hit Circa 5000 BC, the first known pandemic annihilated a prehistoric city in China. Around 439 $\mathrm{BC}$, following the war between Athens and Sparta, 100,000 people died in Ancient Greece. In Antonine plague of 165-180 AD, great physicians like Galen

Correspondence: Shabih H. Zaidi, Otolaryngologist, NHS, U.K.

Email: Shzaidi@hotmail.co.uk had to escape Rome ${ }^{3}$.

The Black Death of 1346-1353 down to Spanish flu of 1918, and then Asian flu of 1957-58, AIDS epidemic of 1981, H1N1 of 2009 -2019, Ebola of 2014-16, the Zika of 2015, SARS and MERS of recent memory to the present COVID-19 are recorded in human history as game changers. ${ }^{4}$

Have we learnt any lessons at all?

Politicians are globally known for their selfish attitude. Generally, they are greedy, power hungry, self-centred and dishonest. What happened during the COVID-19 crisis can only be labelled as the failure of politicians, governments, and powerful people. They had been too busy expanding their powers, imposing wars on poor nations, or simply ignorant of their priorities.

Ethics is the mother of morality. Medical ethics deals with applied ethics in medicine. Bioethics is the study of moral values applied in medicine and allied fields.

It appears that states failed at all levels of ethics. NHS, UK, was introduced after the Second World War by Ernest Bevin. a miner's son from South Wales near Rhonda valley, famous for coal mines, TB, Typhoid, Cholera, Meningitis and many other killers. Bevin revolutionized healthcare in this country. Based upon egalitarian values and social justice, it opened its gates to one and all. Healthcare at the first point of contact based upon needs not greed, affordability, or status, it provided the same service to the duke as to the dust man.

I joined the NHS, when it was only 20 years old. Some of the pre-war isolation hospitals and sanatoria were our training centres. A consultant, a matron and a hospital secretary ran the service smoothly, as you may have seen in the old films. NHS produced such heroes as Adeeb Rizvi, Rab, Saleh Memon, Fazle Elahi, Khwaja Sadiq, Shafi Qureshi, Saeed Qureshi, and numerous pioneers of health and education in Pakistan. But then things changed.

NHS expanded overtime. Knowledge and skills have expanded exponentially over the last several decades. What began as a service to the sick has now been

Ann Jinnah Sindh Med Uni 2020; 6(1): 1-2 
merged with social care. It has literally broken its back. Ageing population means co-morbidities duly augmented in the West by lack of family support. Western culture is like a ragged piece of Napoleonic tapestry, with unmendable holes and fibre which is threadbare. Lack of family support means no one is there to take care of the elderly. So, Mother's Day is important as is a Christmas card, as a polite reminder that we care but we can't live with you.

In contrast to that, look at the Eastern culture, which is like a finely woven, intricately patterned Persian gleem. Every fibre intertwined with the other, called tana bana giving it strength and durability. To have an elderly in the house is a blessing for Eastern people.

So the COVID-19 demolished the elderly folks living in care homes, like the Australian bush fire. Could a vaccine save loss of human life? Possibly yes. But here is what is happening on the vaccine front. Anti-vaccine campaign has already started even as the scientists are busy finding one.

Pakistan is one of the two or three countries in the world where Polio continues to remain a nightmare. The whole world knows who is behind this. The faultline seems to lie in certain areas where ignorance continues to remain a bliss and the clergy rules. On 6 May 2020, a Pakistan TV channel duly highlighted a worrying situation that many children have failed to be vaccinated in Pakistan due to the lockdown. A few cases of measles and mumps have been reported in Karachi in April 2020. Sad but true.

A few years ago, similar opposition was faced by the volunteers who went to the mountainous terrains of northern Pakistan to introduce iodised salt as goitre is pandemic in that region. Strong resistance including the false news that anyone who consumed iodised salt would become either impotent or sterile, led to near failure of the project. Some religious scholars were against to build a dam due to ignorance that water from dam is still water and would not be suitable to make ablution.

A paediatrician published a report a few years ago, linking up some cases of autism with the MMR. Many parents in the U.K. as indeed in several Eastern European countries thereafter refused to get their children vaccinated. Numerous cases of measles were reported in the last few years worrying public health authorities.

And now comes the latest story. COVID-19, a nanoparticle which is no more than a fat covered genetic material, has brought the world to its knees in the spring of 2020.
Intense search for drugs or vaccines is going ahead. So, last week it was announced that an Oxford University lab is on the verge of finding a vaccine. However, it was developed from the cell line of a human foetus aborted in 1972, but preserved for scientific research. Immediately, the ethicists jumped into the ring. A report published by the renowned Bioethics group, raised their concern on the morality of the use of an aborted foetus. ${ }^{5}$

All monotheistic faiths condemn abortion unless it is to save the mother's life. Much debate has gone on to lower the age of allowable abortion from 22 weeks to 14 weeks of gestation, as the neural crest develops immediately after the 14th week. And the neural crest is the precursor of the brain which means conscience which means the heart is already developed and the foetus is alive though vegetative in nature.

The bone of contention is the use of aborted foetal tissue for developing germ cell line. Until recently, spare embryos after an IVF cycle were saved for such research; but now the Islamic countries in particular have mandated that such spare embryos should be allowed to perish naturally.

Anti-vaccine campaigners argue that if an anti COVID19 vaccine is developed from a human embryo, they will boycott it. ${ }^{5}$ What is worse is that a world champion of a very famous sport of a huge following has emerged as the anti-vaccine campaigner. What can one say except repeat the same old saying that you can debate with a wise person but shouldn't argue with an ignorant one?

Scientists have solved at least one dilemma. That the embryonic tissue may not be needed as other sources may be available. But the point is that with thousands of deaths across the world are you looking for a messiah to come save you?

For God's sake, be humane, be positive and save mankind scientifically. Can any faith based upon rationality and reason justify loss of human life or disabilities? And the same message goes out to the opponents of Polio immunization.

Let knowledge and reason prosper! Let sense prevail!

\section{References}

1.The Noble Quran.5:32 .

2.Google: Johns Hopkins Coronavirus Resource Centre, accessed on 5 May 2020

3.http://www.nytimes.com/2020/04/92/opinion/Coronavirusdoctors-duty.html

4. Google scholar : accessed on 6,May 2020

5. https://catholicherald.co.uk/catholic-bioethicist-no-needto-shun-covid-19-vaccine-derived-from-aborted-babies/ 